\title{
CHARLES J. GUIGUET'S BOYHOOD ACTIVITIES AS A NATURALIST AND COLLECTOR AT SHAUNAVON, SASKATCHEWAN
}

Spencer G. Sealy

Department of Biological Sciences

University of Manitoba

Winnipeg, MB R3T 2N2

Spencer.Sealy@umanitoba.ca

Charles J. Guiguet's far-reaching contributions to the field of natural history in British Columbia focused particularly on seabirds and insular mammals - have been chronicled extensively. ${ }^{1-3}$ Less well known is that Guiguet's interest in natural history took hold in Shaunavon, Saskatchewan, where he was born in 1915, shortly after his parents immigrated to Canada from France. By the time he graduated from high school in Shaunavon in 1935, his interest in the natural world had developed, initially under the influence of supportive parents. In his spare time, Charles's father, Laurent Guiguet, a carpenter and painter, assembled a collection of insects, mostly butterflies ${ }^{4}$, to which the younger Guiguet contributed, but most of his activities focused on collecting birds and mammals. These led to an interest in museums, whereby Charles eventually parlayed his experiences into a lifelong career as a field biologist and museum curator, in British Columbia, to where his family moved in 1936. Guiguet's boyhood activities as a naturalist and collector, strongly supported by teachers at his school and staff of the local museum, and influenced by established naturalists and ornithologists, provide a glimpse into the state of natural history in southern Saskatchewan nearly 100 years ago.

\section{A Naturalist in the Making}

Guiguet's collecting activities

in Shaunavon were undertaken in association with his teachers at the local school and the staff of the recently opened Grand Coteau Museum (GCM, now Grand Coteau Heritage \& Cultural Centre; hereafter Museum). In the winter of 1932 , the Museum engaged the services of a taxidermist, Frank D. Steffan, who quickly set about augmenting the Museum's exhibits. ${ }^{5}$ Realization of the need for additional mounted specimens, Steffen instructed a group of local boys, including Guiguet, in the art of taxidermy. Charles quickly showed promise, winning first prize in a taxidermy contest held early in 1932, the year following the opening of the Museum. ${ }^{6}$ One of the founders of the Museum, and the judge of the contest, was Charles F. Holmes, a pioneer naturalist-rancher who homesteaded south of present-day

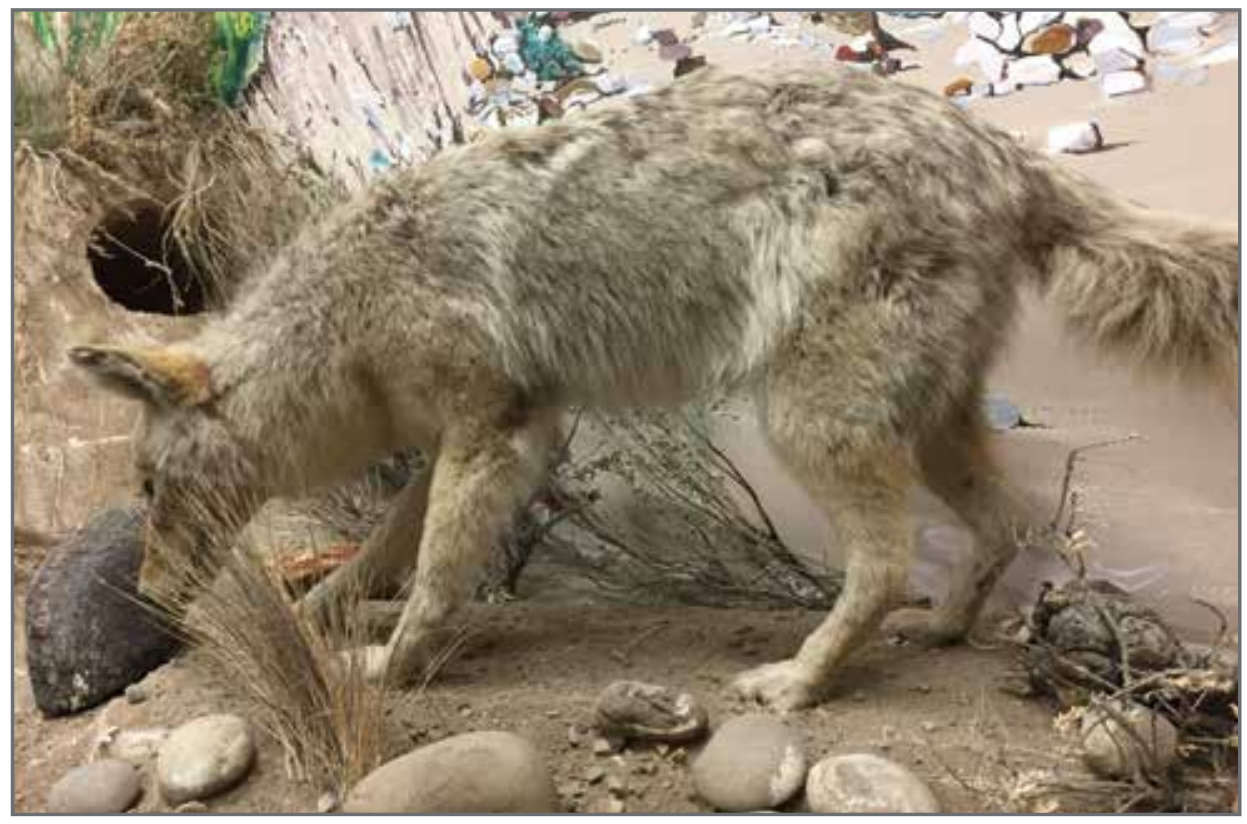

FIGURE 1. Coyote (Canis latrans) mounted by Charles Guiguet is on exhibit at the Grand Coteau Heritage \& Cultural Centre, Shaunavon. Photo credit: N.L. Sealy. 
Federal Game Officer for the western Canadian Provinces, and prodigious bird collector. ${ }^{8}$ In June 1931, Munro addressed students in Grades 5 to 10 in the local school on the economic value of birds, showing slides of nests of several species of Canadian birds and their habitats. ${ }^{9}$ Charles was in Grade 10 and was undoubtedly among those present. One may imagine the effect of Munro's talk on young Charles. Less than a year later, he won the taxidermy contest held at the Museum and, in 1933, a second opportunity arose for the boys to meet with Munro. ${ }^{10}$ This time, Munro was a guest at the Holmes homestead during one of his tours of inspection of waterfowl habitats on the Prairies. ${ }^{11}$ Probably arranged by Holmes, Munro showed Guiguet and other boys how to properly prepare study skins for permanent storage in a museum for scientific study..$^{10}$ It has been stated that the specimen used for instruction that day was a Black-footed Ferret (Mustela nigripes) that school children had shot ${ }^{3}$, but this has not been confirmed. Guiguet later prepared two ferret specimens that were presented to the National Museum of Canada, leaving the whereabouts of the putative demonstration specimen unknown. Soon, armed with his own scientific collecting permit issued by the Federal Government - the youngest person to qualify at the time ${ }^{10}$ - and newly acquired skills, Guiguet began to prepare specimens accompanied with the locality and date of collection, and other pertinent information that confirmed, in some cases, records of historical importance and first occurrences of species in Saskatchewan and Canada.

A constant throughout the Shaunavon years was Holmes's recognition of Guiguet's potential as a museum biologist and collector. Holmes's support was important because of his stature in the local community. Stuart Houston highlighted many of the contributions Holmes made to the development of Shaunavon through memberships in the Fish and Game League and Canadian Club, and as a founding member of the Grand Coteau Museum. ${ }^{7}$ Noted previously, Holmes had judged Guiguet's winning entry in a taxidermy contest but, in turn, Holmes was the beneficiary of Guiguet's collecting skills.

\section{The collections}

I wondered whether any of Guiguet's specimens became part of Charles Holmes's collection and if his hand in collecting and/or preparing them was indicated on the labels, or whether Holmes took credit for the specimens. Holmes's collection consisted of more than 600 specimens, mostly birds but also of several mammals. The Holmes family eventually presented about 500 specimens to the Alberta Provincial Museum, now Royal Alberta Museum (RAM), in Edmonton, in $1980^{7}$ (J. Hudon, email, 6 September 2019). Lesser numbers of specimens had been transferred to Saskatchewan Natural History Museum, now Royal Saskatchewan Museum (RSKM), in 1963 (D. Frier, email, 25 June 2019), Royal Ontario Museum (ROM), several of which were taken later by his son, Paul M. Holmes (B. Millen, email, 15 July 2019), and National Museum of Canada, now Canadian Museum of Nature (CMN; G. Rand, email, 7 September 2019). At least 15 study skins (8 birds and 7 mammals) Guiguet collected in the years before the family left Shaunavon also are catalogued in the CMN. Originally deposited in the Museum, these specimens were transferred by volunteer curator Herbert F. Hughes to the CMN in 1935 (G. Rand, email,
29 May 2019), where they still reside.

Holmes was named as collector of most specimens, including those taken at Shaunavon, but there were a few exceptions. In addition to the specimen of Calliope Hummingbird (Selasphorus calliope) noted below, Guiguet's name was given as collector of two species: adult female Bohemian Waxwing (Bombycilla garrulous; RAM Z80.120.178) taken on February 1932 and adult male Ruddy Duck (Oxyura jamaicensis; RAM Z80.120.315), 11 May 1935. In addition to Holmes's name as collector credit was given on two specimens of Gray-crowned Rosy Finches (Leucosticte tephrocotis; RSKM_BIRD_A-3367, A-3368) to Laurence B. Potter at Eastend, another rancher-naturalist of the Cypress Hills ${ }^{12}$, and Townsend's Solitaire (Myadestes townsendi; RSKM A-2728) prepared by $\mathrm{H}$. Hedley Mitchell, who compiled the first catalogue of Saskatchewan birds. ${ }^{13}$ If Guiguet had collected and/ or prepared specimens that became part of Holmes's collection, he was given credit.

Among Guiguet's specimens registered in the $C M N$ are two Blackfooted Ferrets, the first (CMNMA 12682) salvaged near Shaunavon in 1934 (Figure 2), whereas the other specimen (CMNMA 14078) was taken near the former hamlet of Senate in the extreme southwestern corner of the province, in 1935, and submitted salted for preparation later as a study skin. They are among the few Black-footed Ferret specimens, and the last, catalogued in museums that provide permanent records of occurrence of this species at the northern edge of its historical range ${ }^{14-16}$, before the species largely disappeared from the Saskatchewan landscape.

A specimen of Black-footed Ferret (Figure 3), faded after years 


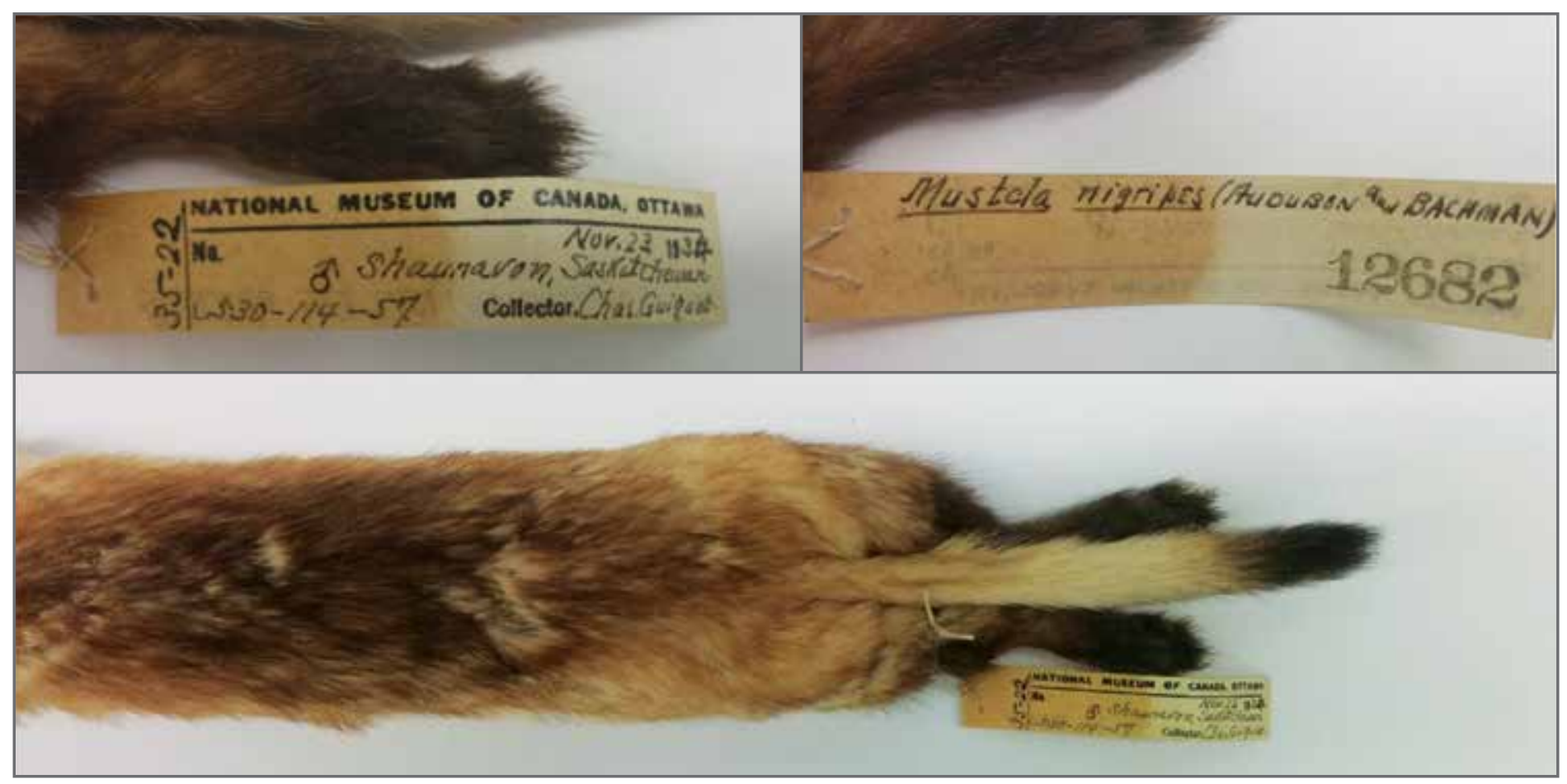

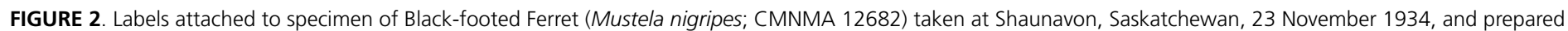
by Charles Guiguet. Photo credit: G. Rand.

on exhibition in the Museum, was killed in a haystack near Val Marie, Saskatchewan, in $1965^{16}$, about 30 years after Guiguet left Shaunavon. The specimen disappeared about 20 years ago during renovations of the Museum's natural history room (K. Attrell, email, 22 May 2019). Upon realization of the rarity of this species, the mounted ferret may have been transferred to another museum for permanent storage, but there is no record of this, and contacts with several curators (see acknowledgements) did not turn up this specimen.

Black-footed Ferrets had been recorded as last observed in Canada in 1937 and were formally designated as extirpated in $1978^{17}$, but this record and several accepted observations revealed its presence through the mid-1980s, "well beyond the range of Black-tailed Prairie Dogs." 16 The population declined rapidly in the early 1900s, caused in part by cultivation of habitat, programs to eradicate the Black-tailed Prairie Dog (Cynomys ludovicianus), the ferret's principal prey, and diseases. ${ }^{17,18}$ Efforts to re-establish the Black-footed Ferret in Saskatchewan are underway. ${ }^{19}$ Guiguet's specimen of Black-tailed Prairie Dog (CMNMA 12681, 31 July 1934) taken at Shaunavon provided another permanent record of this species' occurrence within the radius of historical colonies recorded in Beck's A Guide to Saskatchewan Mammals. ${ }^{15}$

Other mustelids also were of interest. In late November 1932, a note appeared in the local newspaper stating that a dead weasel recently received by the Museum had been "forwarded to Ottawa \& not satisfactorily identified." It lacked black on the tip of the tail, but because the skull was not submitted, its identity as a Least Weasel (Mustela nivalis) was not confirmed. ${ }^{20}$ Guiguet's two specimens of Least Weasel (CMNMA 12679, 24 August 1935; CMNMA 12680, _ 1934) confirmed Shaunavon as another locality within the species' range in southwestern
Saskatchewan. Although those specimens were not recorded in Beck's Guide ${ }^{15}$, others of this species were listed from nearby Eastend (taken by J. Dewey Soper ${ }^{21}$ ) and at Skull Creek, taken by Steven A. Mann, another of the ranchernaturalists of the Cypress Hills whose legacy of observations and specimens endure. ${ }^{12}$ Still in Holmes's collection and therefore not included in Beck's Guide, was a Least Weasel later presented to the Saskatchewan Natural History Museum (now Royal Saskatchewan Museum, RSKM_ Mamm_2271) collected at Dollard around 1929. Holmes's specimen may have been among the mounts held in the Museum at the time, to which Guiguet referred in one of several pieces published in the local newspaper under the heading "Student News." 22 In addition to this specimen, Holmes presented three preserved Long-tailed Weasels ( $M$. frenata; CMNMA 11758-59, 12298), taken in 1933, to the CMN (G. Rand, email, 4 September 2019).

The scent glands of ferrets and 


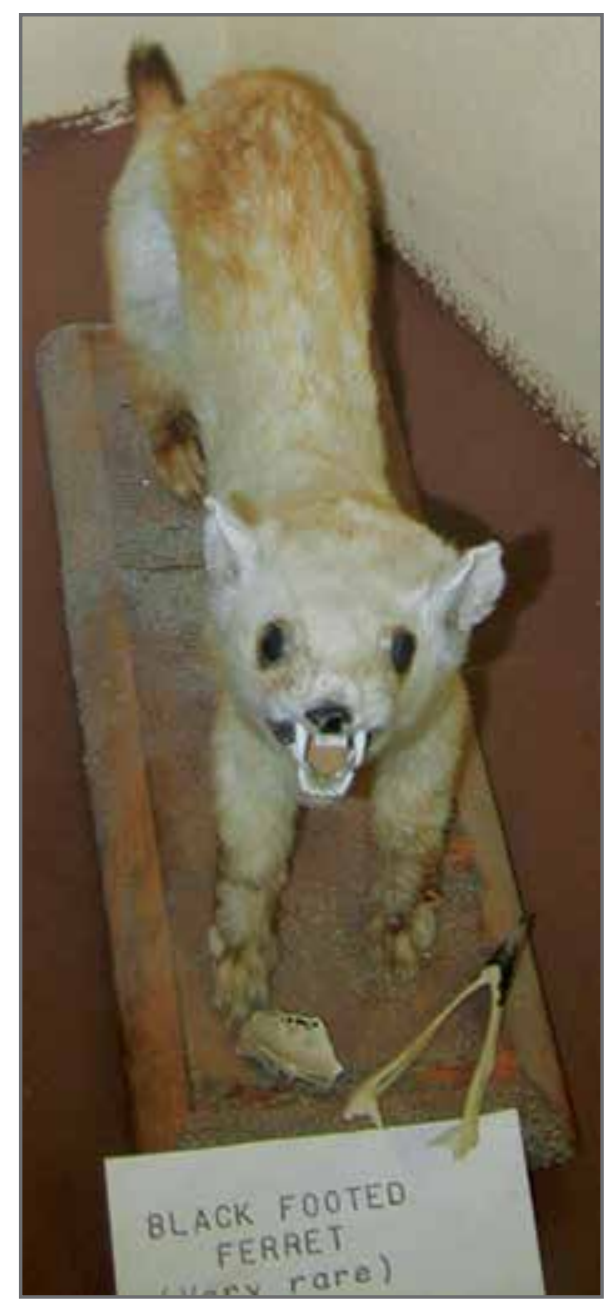

Figure 3. Mounted Black-footed Ferret (Mustela nigripes) killed near Val Marie, Saskatchewan, in 1965. Photograph courtesy of Grand Coteau Heritage \& Cultural Centre, Shaunavon.

weasels presented special challenges to the young taxidermist, but the preparation of a specimen of the Striped Skunk (Mephitis mephitis) caused quite a stir in the local school, as revealed in the following tribute to the museum's curator. ${ }^{23}$

The mammals department was aided by science teachers. Jack [Hughes] tried to stay out of trouble but one incident is worthy of note. The subject for mounting was a skunk, the student taxidermist was Charles Guiguet. Jack made sure that he knew the correct procedure for removal of the scent gland, and left, leaving Charles to finish and lock up. The nest day was Saturday. On Monday the schools opened as usual, but immediately all the students of the junior building were sent home. Charles had removed

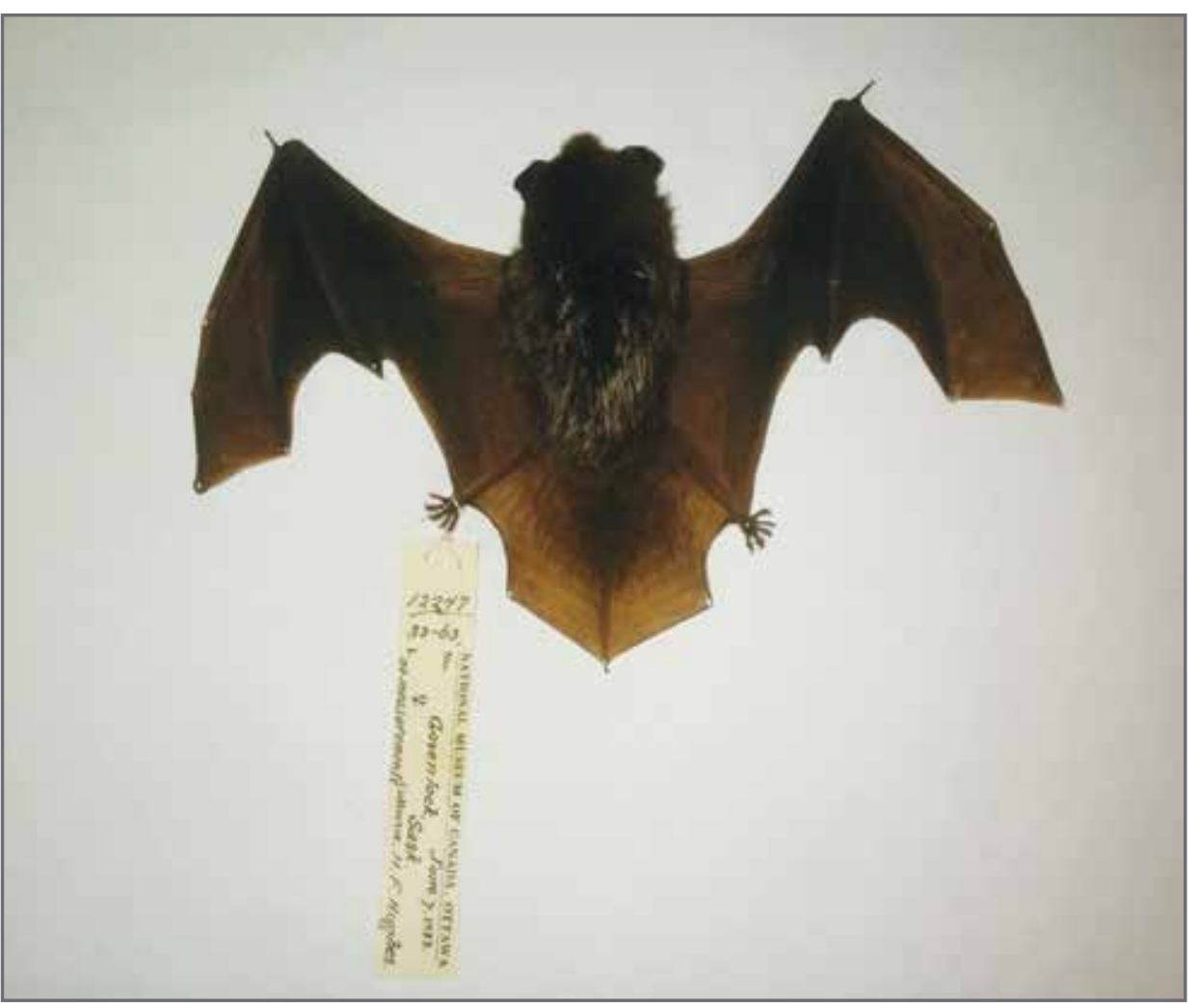

FIGURE 4. Silver-haired Bat (Lasionycteris noctivagans, CMNMA 12247) taken by H.L. Dixon at Govenlock, Saskatchewan, on 7 June 1933, was prepared by C.J. Guiguet. H.F. Hughes, curator of the Museum at the time, was named as collector. Photo credit: G. Rand

the scent glands just fine. Then, $\ldots$ he had left them neatly on the heat register of the Grade Eight classroom. The school was closed for two days. The museum survived [but apparently the mounted skunk did not]. Charles went on to become the head of the Mammal Department in Victoria, B.C.

Guiguet's bat specimens brought further accolades. His specimen of Hoary Bat (Lasiurus cinereus; CMNMA 12683) collected at Shaunavon on 1 September 1934 was apparently the first specimen of this species taken in Saskatchewan. ${ }^{24}$ A Silver-haired Bat (Lasionycteris noctivagans; CMNMA 12247) was taken at Govenlock in the extreme SW corner of Saskatchewan by Dr. Hugh L. Dixon, rancherveterinarian, on 7 June 1933 (Figure 4). Guiguet's preparation of this and other specimens elicited praise from Rudolph M. Anderson of the National Museum of Canada, who wrote to the local newspaper: "Please convey my compliments to Charles Guiguet for the fine makes of skins he is turning out." 25 Reference was made to this Silverhaired Bat specimen in the first compilation of Saskatchewan bat records ${ }^{24}$, whereas this specimen and another allegedly taken at the same locality and on the same date were tabulated in an update of this species' status in the Province ${ }^{26}$, although only one specimen was catalogued in CMN (G. Rand, email, 4 September 2019).

Credit goes to Guiguet for helping to sort out the identities of hummingbirds that occurred in southwestern Saskatchewan. Identification of hummingbirds, particularly females and juveniles, was difficult without specimens. Laurence Potter, a friend of Holmes ${ }^{12}$, noted that "Hummingbirds are seen not infrequently in flower gardens, but public opinion in general is opposed to shooting, so their identity, whether rufous, calliope, or ruby-throated, remains 
undetermined." 27 Sight records of Ruby-throated Hummingbirds (Archilochus colubris) were backed by one found dead at Eastend in August 1925. ${ }^{28}$ Several Rufous Hummingbirds (Selasphorus rufus), another western species, were found dead, in late July and early August. ${ }^{27-31}$ None of these specimens was located, although a badly decomposed bird was entered into the Museum's catalogue, salvaged on 13 August 1932. Since then, with more than 30 records, Rufous Hummingbird is designated as a straggler in Saskatchewan ${ }^{31}$, whereas the Ruby-throated Hummingbird is common and regularly breeds in the Province. ${ }^{32}$

The status of another western species of hummingbird in Saskatchewan - Calliope Hummingbird — remains as "accidental" on the basis of Guiguet's specimen"33, a juvenile shot (not found dead ${ }^{34}$ ) in a Shaunavon

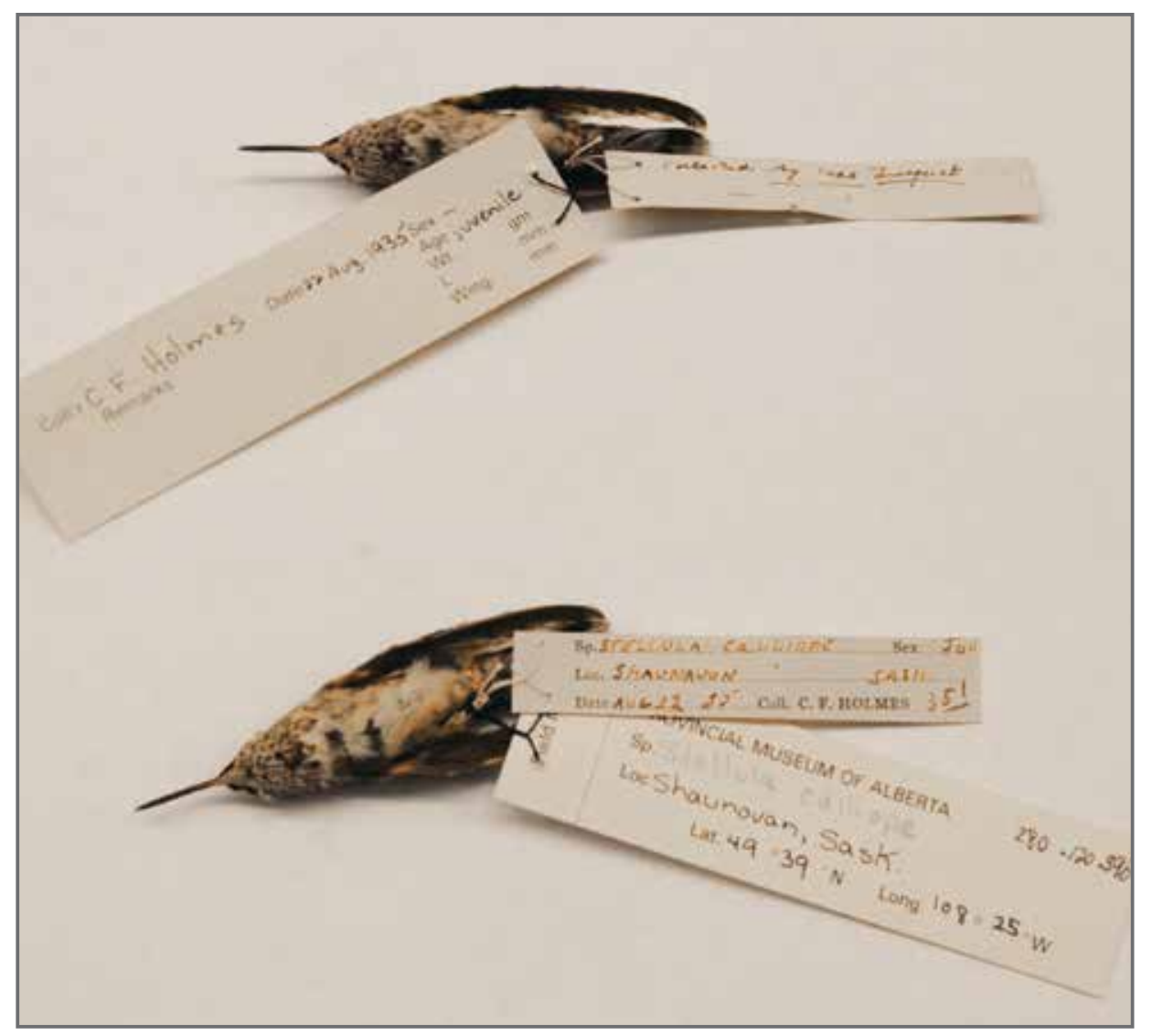

FIGURE 5. Calliope Hummingbird (Selasphorus calliope, RAM Z80.120.396) taken by Charles Guiguet at Shaunavon on 22 August 1935. Photo credit: J. Hudon.

\section{After Shaunavon}

Charles Guiguet's early life as a naturalist in Shaunavon was not unlike that of many other young naturalists. He received considerable encouragement and support along the way, first on the home front, and later from teachers in his school and the staff of the local museum. With his solid work ethic, he seized opportunities and honed his collecting skills through a succession of mentors, all of which placed him in good stead for a career as a field biologist and curator. Success eventually led to the curatorship of birds and mammals at the British Columbia Provincial Museum (BCPM; now Royal British Columbia Museum), but not before he gained additional experience assisting with other projects. Now in British Columbia, Guiguet was invited to join a field party organized by Hamilton Mack Laing to collect specimens for Anderson, now Chief, Division of Biology at the National Museum. Laing was embarking on a four-year faunal reconnaissance of several regions in British Columbia and was able to hire one assistant each year, starting in 1936. ${ }^{37}$ Charles was hired on the strong recommendation of Anderson and, as it turned out, he stayed on as a member of the field party for the next four years (Figure 6). Anderson endorsed Guiguet's collecting skills in a letter to Laing in $1936^{38}$ :

Mr. Charles G. [sic] Guiguet ... 20 years old, [has] passed senior matriculation at Shaunavon, Saskatchewan. He has collected for Shaunavon "Grand Coteau Museum" for several years, and makes good mammal and bird skins, and has sent me a number. He needs a job and some encouragement. $\mathrm{H}$. F. Hughes [volunteer GCM curator] thinks he is a coming naturalist, if he gets half a chance. He wants to go to college if he gets enough money ahead to make a start. If 


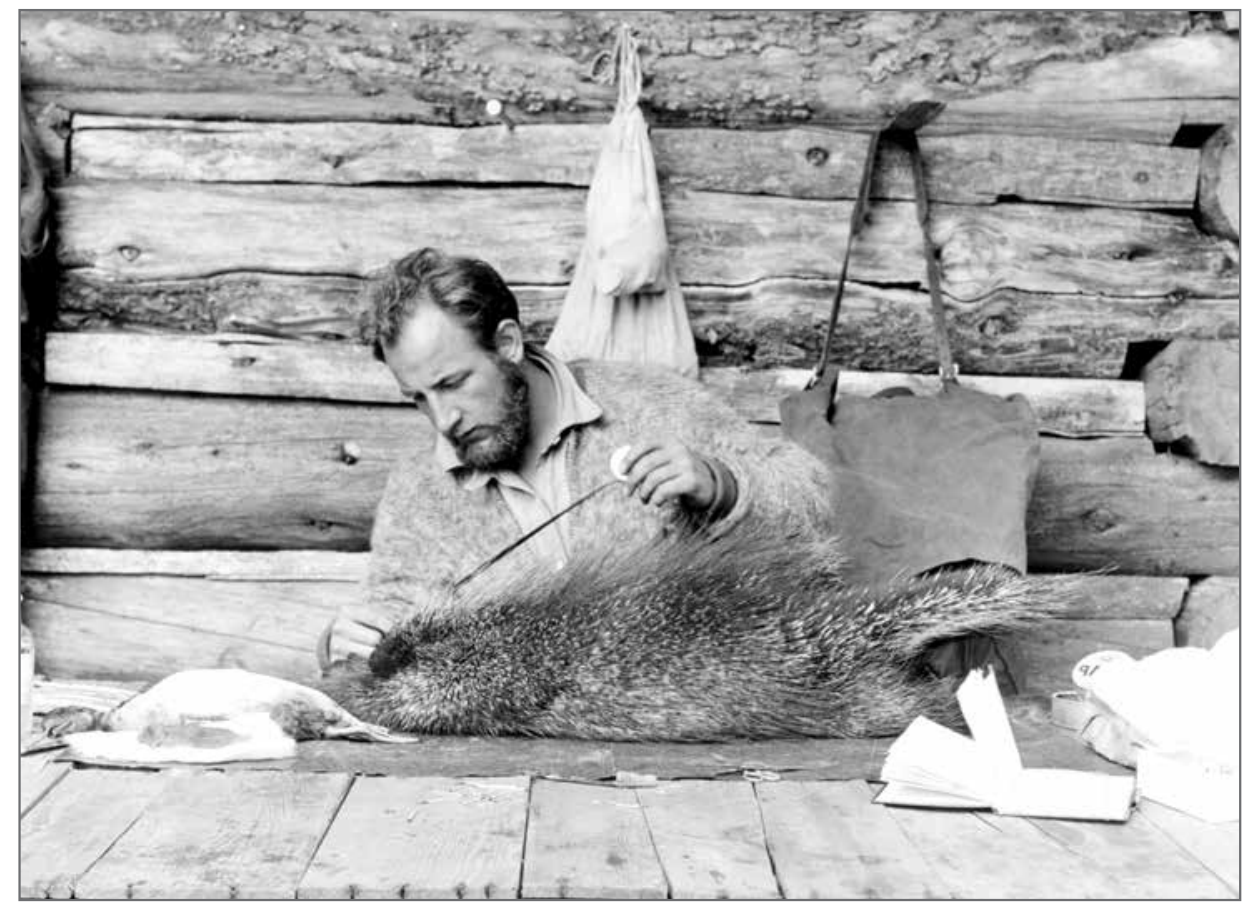

FIGURE 6. About two years after leaving Shaunavon, Charles Guiguet is shown preparing a specimen of the North American Porcupine (Erethizon dorsatum), near Stuie, British Columbia, 16 September 1938. Photo credit: Hamilton Mack Laing; image G-03674, courtesy of Royal British Columbia Museum and Archives.

you take Guiguet you will have one boy who is willing to work at anything, industrious and full of ambition, who will be able to help you turn out a good line of mammal and bird skins, and help at any kind of work around camp.

Word of Guiguet's collecting skills likely reached Laing through additional sources. Considering that Guiguet was a protégé of Holmes, and that Holmes had hosted James Munro at the family homestead, and that Munro knew both Anderson and Laing, the level of Guiguet's skills likely had become general knowledge. All of these men knew lan McTaggart-Cowan, under whose guidance Guiguet soon was collecting specimens for the BCPM and the University of British Columbia (UBC), and under whose supervision Guiguet studied zoology following service in WW II. A long and mutually beneficial association ensued between Cowan, the mentor, and Guiguet, initially the student. Their association began in the era of museum collectors and curators, but it transitioned to the documentation of wildlife distribution and abundance. Many activities conducted by the two men have been highlighted in recent tributes to Cowan. ${ }^{39,40}$

Guiguet was hired by the BCPM in 1948. During his long career he undertook field inventories that took him to some of the most remote and difficult-to-reach regions of British Columbia, including many sites along the Pacific coast where he contributed new information on the biology of coastal fauna, especially seabirds ${ }^{41,42}$ and insular distribution of mammals. ${ }^{43-45}$

\section{Giving back}

Guiguet gave back to his community. He was an active participant in school activities, including sports, and his popularity led to his election as leader of the cheer-leading team. ${ }^{46} \mathrm{He}$ penned numerous contributions for the local newspaper, some under the heading of "Student News", and he sent updates of his activities back to his home town after moving to the west coast (Figure 7). Particularly impressive was Charles's encouragement of other boys to participate in taxidermy sessions in the museum and in the establishment of a museum in the school from which all students benefited, and apparently the teachers, too. Correspondence between the school's principal and Chief Game Guardian in Regina, archived in the Grand Coteau Heritage \& Cultural Centre, however, revealed concern that one museum in Shaunavon was enough. ${ }^{47}$ With assurance that specimens would not be duplicated, and strongly supported by the principal and teachers, a compromise was reached and specimens for display were distributed between the school and local museum. Feral pigeons were used for the taxidermy lessons. The community showed its appreciation by honouring Charles and his brother Marcel, "when a capacity crowd of young people filled the Legion Hall at a farewell dance", before the family left for British Columbia. ${ }^{48}$

\section{Epilogue}

I knew Charles Guiguet, initially through correspondence while preparing to conduct field research on seabirds in British Columbia in the early 1970s. A few years later, while on sabbatical leave at the British Columbia Provincial Museum, I was able to discuss with Guiguet projects planned for Barkley Sound on the west coast of Vancouver Island. I tapped his vast experience gained while he worked at many localities along the coast, including my first study site, Langara Island on Haida Gwaii. Charles always responded in great detail to my inquiries, with an eye to enhancing the success of our endeavors. More recently, Charlie's field notes have provided important observations in support of work 
4

Charles

Guiguet,

formerly of Shaunavon, and now of Vancouver, B.C., has jolned a survey group for the National Muscum for the summer. This is good news to Charles' many friends In Shaunavon, who will wish him success in a work for whlch he Ls well fitted. He was the enthusiastle member of many collecting partles for the local Grand Cotenu Museum, and specimens of his work at the museum would indicate that Charles has a glft for this work, and his position as collector and cook with the nallonal museum party will be a novel experfence and a help in furthering what Charles hopes to make his life's employment.

FIGURE 7. Charles Guiguet updated his friends in Shaunavon, stating he had joined a field party of the National Museum of Canada led by Hamilton Mack Laing. The Shaunavon Standard, 25 June 1936.

underway on a volume focused on ornithological exploration and research on and near Langara Island. Guiguet was awarded a Lifetime Achievement Award by the Pacific Seabird Group in 1995. He died in Victoria on 27 March 1999, but his accomplishments live on.

\section{Acknowledgements}

I am especially indebted to Kelly Attrell for her interest and considerable effort in providing information archived in the Grand Coteau Heritage \& Cultural Centre in Shaunavon, Saskatchewan, and for hosting a visit to examine specimens and other material under her care. Kathleen East, of the same institution, scanned several archived newspaper articles. Kelly-Ann Turkington provided a photograph and Sheila Norton located the Anderson letter archived in the Royal British Columbia Museum and Archives, respectively. I am indebted to curators of the Beaty Biodiversity Museum, University of British Columbia, Vancouver (Ildiko Szabo); Canadian Museum of Nature, Ottawa (Gregory Rand); Royal Alberta Museum, Edmonton (Jocelyn Hudon); Royal British Columbia Museum, Victoria (Lesley Kennes); Royal Ontario Museum, Toronto (Burton Lim, Brad Millen, Mark Peck); and Royal Saskatchewan Museum, Regina (Danae Frier, Ray Poulin, Cory Sheffield). N.L. Sealy assisted in many ways throughout this project. Mark Guiguet put his family's stamp of approval on the final version of the manuscript.
1. Mortimore GE (1954) This week's profile [Charles J. Guiguet]. Daily Colonist, Victoria, B.C., January 31, 1954, pages 1, 12

2. Campbell RW, Dawe NK, McTaggartCowan I, Cooper JM, Kaiser GW, McNall MCE (1990) The birds of British Columbia: Volume 1 - Introduction, loons through waterfowl. Royal British Columbia Museum, Victoria, BC.

3. Carter HR (1996). Charles Joseph Guiguet: Recipient of PSG lifetime achievement award. Pacific Seabirds 23:9. Also see Carter $H[R]$ (1999) In Memoriam: Charles Joseph Guiguet. Pacific Seabirds 26:65-66

4. Anonymous (2016) Treasured insect collection returns to Sask[atchewan]. https://thestarphoenix.com/life/bridges/ treasured-insect-collection-returns-to-sask (accessed 2 June 2019). (The Guiguet family donated Laurent Guiguet's insect collection to the University of Saskatchewan, but the collection was later transferred to the Department of Entomology, Royal Saskatchewan Museum, Regina [C. Sheffield, email, 3 July 2019].)

5. Anonymous (1932) The Shaunavon Standard, 21 January 1932.

6. Anonymous (1932) Prizes presented for taxidermy skill. The Shaunavon Standard, 24 March 1932

7. Houston CS (2013) A biographical sketch of pioneer naturalist Charles F. Holmes, 1888-1948. Saskatchewan History 64:2431, endnotes pages 51-52.

8. Baillie JL (1969) In Memoriam: James Alexander Munro. Auk 86:624-630.

9. Anonymous (1931) Bird expert speaks to students Tuesday. The Shaunavon Standard, 11 June 1931.

10. Anonymous (1933) The Shaunavon Standard, 15 June 1933. (While in the Shaunavon area, James Munro collected three birds on 12 June 1933 [Lark Bunting Calamospiza melanocorys: ROM Birds 83146, 83147; Chestnut-collared Longspur Calcarius ornatus: ROM 84789].)

11. Munro JA (1929a) Glimpses of littleknown western lakes and their bird life. Canadian Field-Naturalist 43:70-74, 99-103, 129-133, 152-155, 181-187, 200-205.

(These accounts predate the first meeting between Munro and Guiguet and the other students, but they reveal the nature of Munro's travels across the Prairies while assessing waterfowl habitat.) 
12. Houston CS, Houston MI (1979) Four rancher-naturalists of the Cypress Hills, Saskatchewan. Blue Jay 37:9-19.

13. Nelson EC, Houston CS (2015) In Memoriam: Horace Hedley Mitchell, 1868-1953. Blue Jay 73:92-95.

14. Anderson RM (1946) Catalogue of Canadian recent mammals. National Museum of Canada, Bulletin, No. 102.

15. Beck WH (1958) A guide to Saskatchewan mammals. Saskatchewan Natural History Society, Special Publication, No. 1.

16. Laing Rl, Holroyd JL (1989) The status of the Black-footed Ferret in Canada. Blue Jay 47:121-125

17. COSEWIC (Committee on the Status of Endangered Wildlife in Canada) (2009) Assessment and addendum on the Blackfooted Ferret Mustela nigripes in Canada. COSEWIC, Ottawa, ON.

18. Henderson FR, Springer PF, Adrian R (1968) The Black-footed Ferret in South Dakota. Department of Game, Fish and Parks, Pierre, South Dakota.

19. Wruth A, Fargey KS, Fargey P (2010) Black-footed Ferret reintroduction in Grassland National Park, Saskatchewan. Blue Jay 68:133-136.

20. Anonymous (1932) Museum requests weasel specimens. The Shaunavon Standard, 17 November 1932.

21. Soper JD (1946) Mammals of the northern Great Plains along the International Boundary in Canada. Journal of Mammalogy 27:127-153.

22. Guiguet CJ (1933) The Least Weasel. The Shaunavon Standard, 30 November 1933.

23. Knoblach M (1996) [Tribute to] Herbert Frank Hughes. Page 95 in Stone Memories (edited by members of North Fork Community Club). Unpublished history filed in Grand Coteau Heritage \& Cultural Centre, Shaunavon, Saskatchewan.

24. Rand AL (1943) Bats in Saskatchewan. Blue Jay 1:34.

25. Anonymous (1933) Untitled. The Shaunavon Standard, 10 August 1933.

26. Nero RW (1957) Saskatchewan Silverhaired Bat records. Blue Jay 15:38-41, 46.

27. Potter LB (1943) Bird notes from southwestern Saskatchewan. Canadian FieldNaturalist 57:69-72.
28. Potter LB (1936) Hummingbirds of southwestern Saskatchewan. Condor 38:170.

29. Godfrey WE (1950) Birds of the Cypress Hills and Flotten Lake regions, Saskatchewan. National Museum of Canada Bulletin, No. 120.

30. Anonymous (1936) Ruby-throated Hummingbirds added to Museum. The Shaunavon Standard, 25 June 1936. (Actually Rufous Hummingbirds.)

31. Smith AR (2019) Rufous Hummingbird Page 374 in Birds of Saskatchewan (Smith AR, Houston CS, Roy JF, editors). Nature Saskatchewan, Regina.

32. Johnston D, Fairburn D (2019) Rubythroated Hummingbird. Pages 370-372 in Birds of Saskatchewan (Smith AR, Houston CS, Roy JF, editors). Nature Saskatchewan, Regina.

33. Dickson RD (2019) Calliope Hummingbird. Page 375 in Birds of Saskatchewan (Smith AR, Houston CS, Roy $J F$, editors). Nature Saskatchewan, Regina.

34. Bent AC (1940) Life histories of North American cuckoos, goatsuckers, hummingbirds and their allies. U.S. National Museum Bulletin, No. 176.

35. Potter, L.B. 1943. Saskatchewan bird records made since the publication of Mitchell's catalogue of Saskatchewan birds in 1924. Blue Jay 1:25.

36. Wiebe K (2019) Northern Flicker. Pages 390-391 in Birds of Saskatchewan (Smith AR, Houston CS, Roy JF, editors). Nature Saskatchewan, Regina.

37. Mackie R (1985) Hamilton Mack Laing: Hunter-naturalist. Sono Nis Press, Victoria, B.C. (Also see Houston CS (1987) [Review of] Hamilton Mack Laing, Hunter-naturalist. Blue Jay 45:120-121, in which Guiguet's work with Laing in mentioned.)

38. Letter from Rudolph M. Anderson to Hamilton Mack Laing, 9 May 1936. Royal British Columbia Museum and Archives, MS1309, Box 5, File 1.

39. Jakimchuk RD, Campbell RW, Demarchi DA (editors) (2015) lan McTaggart-Cowan:

The legacy of a pioneering biologist, educator and conservationist. Harbour Publishing, Madeira Park, B.C.

40. Penn B (2015) The real thing: The natural history of Ian McTaggart Cowan. Rocky Mountain Books, Victoria, B.C.
41. Drent RH, Guiguet CJ (1961) A catalogue of British Columbia sea-bird colonies. Occasional Papers of the British Columbia Provincial Museum, No. 12.

42. Guiguet CJ (1971) A list of sea bird nesting sites in Barkley Sound, British Columbia. Syesis 4:253-259.

43. Guiguet CJ (1955) Undescribed mammals (Peromyscus and Microtus) from the islands of British Columbia. Provincial Museum of Natural History and Anthropology, Report for the year 1954. (Guiguet named a subspecies of Townsend's Vole, Microtus townsendii cowani, endemic to Triangle Island, British Columbia, for Ian McTaggart Cowan.)

44. Guiguet CJ (1974) A qualitative inventory of insular mammalian faunas from the west coast of Vancouver Island. Syesis 7:71-77.

45. Cowan I McT, Guiguet CJ (1978) The mammals of British Columbia, seventh printing. British Columbia Provincial Museum Handbook, No. 11.

46. Anonymous (1932) Charles Guiguet chosen as high school cheer leader. The Shaunavon Standard, 29 September 1932.

47. Letters from J. Wilfrid Tait to A.E. Etter, 19 March 1935; Etter to Tait, 6 April 1935; Tait to Etter, 10 April 1935; Etter to Tait, 12 April 1935.

48. Anonymous (1936) Guiguet brothers honored prior to departure. The Shaunavon Standard, 27 February 1936. 